$\xi=-1$

\title{
Durability Studies on Concrete Made Using Pulverized Used Foundry Sand as A Mineral Admixture
}

\author{
Salim.P.M ${ }^{1 *}, B . S . R . K . P r a s a d{ }^{2}$, Seshadri Sekhar.T ${ }^{3}$ \\ ${ }^{1}$ Research Scholar, Civil Engineering Department, GITAM School of Technology,Hyderabad,India \\ ${ }^{2}$ Professor and Head, Civil Engineering Department, GITAM School of Technology, Hyderabad,India \\ ${ }^{3}$ Professor and Dean,NICMAR, Hyderabad, India \\ *Corresponding author E-mail:rawther.salim@gmail.com
}

\begin{abstract}
Durability of the structures is a main concern now a day due to the various types of deteriorations caused by natural as well as manmade environmental conditions. In this project the durability properties of concrete made with pulverized used foundry sand as a mineral admixture is analyzed. The durability of concrete is mostly depends on the surrounding environment. The chemicals present in air and water are the main causes of deterioration of concrete in its life. So a deep study on the action of deteriorating chemicals on the concrete containing pulverized used foundry sand is initiated. Here M40 concrete is prepared with 0\%,5\%,10\%,15\% and 20\% addition of pulverized used foundry sand to the cement content. Cubes of size $100 \mathrm{mmx} 100 \mathrm{mmx} 100 \mathrm{~mm}$ were cast and tested for various parameters like Acid resistance with hydrochloric acid and sulfuric acid, Sulphate attack with sodium sulphate and alkali resistance with sodium hydroxide for. The testing was performed on cubes at 28day, 56 day, 90 day and 180 day stored in respective chemicals dissolved in water at $5 \%$ concentration. From the test results it is inferred that the concrete containing pulverized used foundry sand is better in acid resistance than ordinary concrete without pulverized used foundry sand. Further the acid resistance for both hydrochloric and sulfuric acid shows an increase up to $15 \%$ addition of pulverized used foundry and after that it is slightly reduced. The samples subjected to sodium sulphate and sodium hydroxide has shown no variation in properties with respect to the water cured specimens.
\end{abstract}

Keywords:Acid Resistance; Durability Factor; Mass Reduction Percentage; Pulverized Used Foundry Sand; Sulphate Attack

\section{Introduction}

In earlier days the strength is the only parameter which draws the attention of the engineers and researchers as far as the concrete is concerned .Later it is established that durability is also as important as that of the strength criterion. Durability of concrete may be generally defined as the capability of concrete to resist weathering action, chemical attack, and abrasion without compromising its required engineering properties. A durable concrete is one that performs satisfactorily in the working environment during its anticipated exposure conditions during service[1].The durability parameter is much important for reinforced concrete structures than for normal concrete structures. The durability of reinforced concrete is influenced by those physical characteristics of concrete that control the definition of gases, such as $\mathrm{CO}_{2}$ and $\mathrm{O}_{2}$, or of liquids (mainly water) through its pores, and the diffusion of ions, such as $\mathrm{Cl}-$, dissolved in the pore water [2].Durability is a time dependent property and during the course of time the durability of the structure decreases. The durability of concrete is much influenced by the environment, type of materials used in concrete and water to cement ratio. The other factors influencing the durability of concrete particularly for reinforced concrete are compaction, curing and cover to reinforcement etc. In the present project the durability properties of M40 concrete containing Pulverized Used Foundry Sand (PUFS)at $0 \%, 5 \%, 10 \%, 15 \%$ and $20 \%$ addition to that of the cement content is analyzed for chemical action due to
Hydrochloric Acid ( $\mathrm{HCl})$,Sulphuric $\operatorname{Acid}\left(\mathrm{H}_{2} \mathrm{SO}_{4}\right)$, Sodium Sulphate $\left(\mathrm{Na}_{2} \mathrm{SO}_{4}\right)$ and Sodium Hydroxide $(\mathrm{NaOH})$.

\section{Pulverized Used Foundry Sand}

Used foundry sand is an industrial waste product discarded from the foundry industries. Its volume of production is much all over the world. Normally these are used for filling low lying areas. Many researchers found that the used foundry sand can be used in the production of concrete as a partial replacement to fine aggregates. The chemical constituents of used foundry sand is similar to that of the silica fume .Silica fume is the much widely used mineral admixture for strength enhancements in high strength and high performance concrete. So by pulverizing the used foundry sand we will get fine powder of sand which is having similar properties as that of silica fume. The general chemical constituents of Pulverized Used Foundry Sand (PUFS) are reported in Table1.

Table1.Chemical Properties of PUFS

\begin{tabular}{|l|l|l|}
\hline \multicolumn{3}{|c|}{ Table1.Chemical Properties of PUFS } \\
\hline 1 & Property & Value \\
\hline 2 & Silicon Dioxide $\left(\mathrm{SiO}_{2}\right)$ & $>80.00 \%$ \\
\hline 3 & Loss on Ignition & $<4.00 \%$ \\
\hline 4 & Moisture Content & $<3.00 \%$ \\
\hline
\end{tabular}




\section{Research Significance}

There are a lot of research studies are available on the durability properties of common mineral admixtures like fly ash, metakaolin, ground granulated blast furnace slag and silica fume. But as a newly introduced material no durability studies are available for concrete containing Pulverised Used Foundry Sand (PUFS). So it is of great importance to study the durability properties of concrete containing PUFS.As no literatures are available on the subject material it is initiated to study the durability characteristics of concrete containing PUFS for acid attack due to Hydrochloric Acid $(\mathrm{HCl})$ and Sulphuric Acid $\left(\mathrm{H}_{2} \mathrm{SO}_{4}\right)$, Sulphate attack due to Sodium Sulphate $\left(\mathrm{Na}_{2} \mathrm{SO}_{4}\right)$, alkali attack due to Sodium Hydroxide $(\mathrm{NaOH})$ and Durability Factors.

\section{Literature Review}

N. K. Amudhavalli and Jeena Mathew (2012) studied the effect of silica fume on the strength and durability parameters of concrete [3]. From the study it is concluded that the concrete containing silica fume is more resistant to acid attack and the loss of weight percentage and loss of compressive strength percentage is much lesser than that of the concrete mix without silica fume.

S.Sesha Phani et al (2013) studied the effect of mineral admixtures on durability properties of high strength self compacting concrete [4]. In this they studied in detail the durability characteristics of M100 grade self compacting concrete with different admixtures. From this they found that the percentage weight loss of high strength self compacting concrete mixes after immersing in $10 \%$ $\mathrm{HCl}$ or $\mathrm{H}_{2} \mathrm{SO}_{4}$ solution increases corresponding to the time. The percentage loss of compressive strength of high strength self compacting concrete mixes after immersing in $10 \% \mathrm{HCl}$ or $\mathrm{H}_{2} \mathrm{SO}_{4}$ solution increases corresponding to the time. The percentage weight loss and percentage loss of compressive strength of high strength self compacting concrete mixes after immersing in $10 \%$ $\mathrm{Na}_{2} \mathrm{SO}_{4}$ is observed to be nil for any period of time.

\section{Objectives of Study}

The objective of the present study includes the detailed investigation of the effects of $\mathrm{HCl}, \mathrm{H}_{2} \mathrm{SO} 4, \mathrm{Na}_{2} \mathrm{SO} 4$ and $\mathrm{NaOH}$ on the properties of concrete with and without the addition of Pulverized Used Foundry Sand. This will be performed by conducting tests on concrete cubes stored in fresh water and in respective chemicals dissolved in water at $5 \%$ concentration level at 28 days, 56 days, 90 days and 180 days after the initial curing of 28 days in fresh water.

\section{Materials and Mix Proportioning}

The cement used was OPC 53 grade cement conforming to IS 12269-1987[6].The fine aggregate used was manufactured sand and the coarse aggregate used was crushed rock aggregates. Both the fine aggregates and coarse aggregates were conforming to relevant specifications of ASTM C-33/C33 M-16e1 [7]. The water used was ordinary tap water of potable quality. Pulverized used foundry sand was prepared by pulverizing used foundry sand collected from a foundry in Chavara in Kollam District, Kerala State, India by specially prepared sand pulverizer. Super plasticizer used was Fosroc SP 430 A2 Conforming to IS 91031999[8].

The mix was designed for M 40 grade as per the specifications based on ACI-211.1-1991[8].The cement content used was $430 \mathrm{~kg} / \mathrm{m} 3$.The Pulverized Used Foundry Sand (PUFS) were added to the mix at $5 \%, 10 \%, 15 \%$ and $20 \%$ of the cement content. The concrete mix without the addition of PUFS constitutes the control mix.
Concrete cubes of size $100 \mathrm{mmx} 100 \mathrm{~mm} \times 100 \mathrm{~mm}$ were casted and cured in water for 28 days with 24 numbers in each category as per standard practice.

\section{Test Procedure}

After the expiry of the initial curing in water for 28 days, 12 cubes from each category were removed from water and allow it to dry at room temperature. The weight of the cubes was noted. Dissolve Hydrochloric acid in water at $5 \%$ concentration in separate container having sufficient capacity. The cubes were then immersed in the container with diluted acid with proper identification marks. The procedure is repeated for Sulphuric acid, Sodium Sulphate and Sodium Hydroxide. The $\mathrm{pH}$ of the solution is noted regularly and if differences occurred then additional quantity of chemicals should be added to the solution to make its $\mathrm{pH}$ at constant level.

\subsection{Mass reduction percentage}

Three numbers of the cube specimens stored in the respective chemical solution is taken out at the specified date of testing at 28 days, 56days, 90days and 180 days. The specimens were allowed to dry in room temperature. The loss of weight to the initial weight reported in percentage form is the mass reduction percentage.

\subsection{Compressive strength reduction percentage}

Three numbers of the cube specimens stored in fresh water is taken out at the specified date of testing at 28 days, 56days, 90days and 180 days. The specimens were allowed to dry and tested in a compression testing machine to find out the average compressive strength .Then the specimens of the mass reduction percentage testing is further tested in compression testing machine to get the average compressive strength as per IS 516-1959[9]. The ratio of the difference in compressive strength of the fresh water cured sample and the chemical cured sample to the compressive strength of the fresh water cured sample reported in percentage form is the compressive strength reduction percentage.

\subsection{Durability Factor}

Durability factor is the measure of the change (with time) in the property of a material as a result of exposure to an influence which has the potential of causing deterioration usually expressed as a percentage of the property before exposure[9].For the concrete exposed to environmental conditions the durability factor has great significance. The durability factor is calculated from the following equation.

Durability Factor $\boldsymbol{D} . \boldsymbol{F}=(\boldsymbol{S r} \boldsymbol{x}) / \boldsymbol{M}$

Where $\mathrm{Sr}=$ Relative compressive strength in \%

$\mathrm{N}=$ Number of days at which the durability factor is needed

$M=$ Number of days at which the exposure is terminated

\section{Acid Resistance of Concrete Exposed to $\mathrm{HCl}$}

The mass reduction percentage due to the action of $\mathrm{HCl}$ is maximum for the concrete without PUFS content for all curing ages. Further the mass reductionpercentage decreases up to certain percentage and then it is tends to increase for all curing ages. The mass reduction percentage is reported in Table2. 
Table 1. Mass Reduction Percentage for $\mathrm{HCl}$

\begin{tabular}{|l|c|l|c|c|c|c|}
\hline S1. & \multirow{2}{*}{$\begin{array}{c}\text { \% } \\
\text { No. }\end{array}$} & MUF & & \multicolumn{4}{|c|}{ Mass Reduction Percentage (\%) } \\
\cline { 4 - 7 } & & 28 Day & 56 Day & 90 Day & 180 Day \\
\hline 1 & 0 & C & 1.05 & 1.70 & 2.10 & 2.80 \\
\hline 2 & 5 & F1 & 0.89 & 1.53 & 1.92 & 2.57 \\
\hline 3 & 10 & F2 & 0.82 & 1.37 & 1.77 & 2.35 \\
\hline 4 & 15 & F3 & 0.90 & 1.45 & 1.84 & 2.51 \\
\hline 5 & 20 & F4 & 0.96 & 1.64 & 1.95 & 2.64 \\
\hline
\end{tabular}

For compressive strength reduction percentage also, the concrete without PUFS content exhibits maximum percentage reduction. The reduction percentage is decreasing up to $15 \%$ addition of PUFS and after the strength reduction percentage shows an increase. In all the cases the compressive strength reduction percentage increased with the duration of immersion. The compressive strength reduction percentage is reported in Table3.

Table 2. Compressive strength reduction $\%$ for $\mathrm{HCl}$

\begin{tabular}{|l|c|l|c|r|r|c|}
\hline S1. & \multirow{2}{*}{$\begin{array}{c}\text { \% } \\
\text { No. }\end{array}$} & PUFS & & \multicolumn{4}{|c|}{ Compressive Strength Reduction Percentage (\%) } \\
\cline { 4 - 7 } & & 28 Day & 56 Day & 90 Day & 180 Day \\
\hline 1 & 0 & C & 2.98 & 3.33 & 4.38 & 6.55 \\
\hline 2 & 5 & F1 & 2.85 & 3.19 & 4.20 & 6.21 \\
\hline 3 & 10 & F2 & 2.75 & 2.73 & 4.08 & 6.04 \\
\hline 4 & 15 & F3 & 2.68 & 2.64 & 3.95 & 5.84 \\
\hline 5 & 20 & F4 & 2.79 & 3.12 & 4.14 & 6.14 \\
\hline
\end{tabular}

The graphical representation of compressive strength reduction percentage for $\mathrm{HCl}$ is shown in Fig.1.

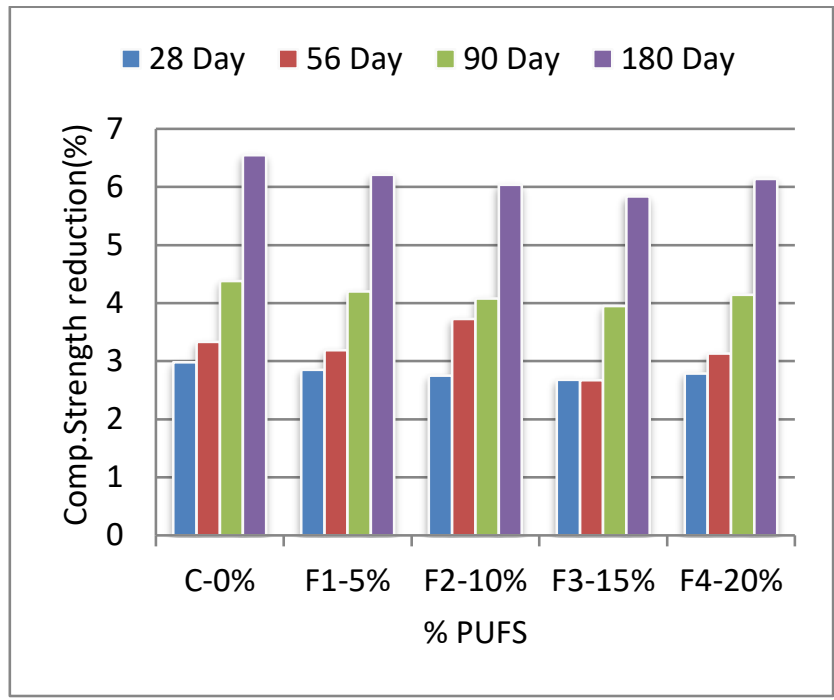

Fig.1.Compressive strength reduction\% for $\mathrm{HCl}$

The durability factors of $\mathrm{HCl}$ are found to be increasing with the passing of time. The durability factors are increasing with the increase in percentage addition of PUFS. The durability factors are tends to increase up to $15 \%$ addition of PUFS. After that the durability factors show marginal decrease up to $20 \%$ addition of PUFS. The durability factors are reported in Table 4.

Table 4.Durability factors for $\mathrm{HCl}$

\begin{tabular}{|l|c|l|c|c|c|c|}
\hline S1. & \multirow{2}{*}{$\begin{array}{l}\text { \% } \\
\text { No. }\end{array}$} & Mix & \multicolumn{4}{|c|}{ Durability Factor (\%) } \\
\cline { 4 - 7 } & & 28 Day & 56 Day & 90 Day & 180 Day \\
\hline 1 & 0 & C & 15.09 & 30.08 & 47.81 & 93.45 \\
\hline 2 & 5 & F1 & 15.11 & 30.12 & 47.90 & 93.79 \\
\hline 3 & 10 & F2 & 15.13 & 30.26 & 47.96 & 93.96 \\
\hline 4 & 15 & F3 & 15.14 & 30.29 & 48.03 & 94.16 \\
\hline 5 & 20 & F4 & 15.12 & 30.14 & 47.93 & 93.86 \\
\hline
\end{tabular}

\section{Acid resistance of concrete exposed to $\mathrm{H}_{2} \mathrm{SO}_{4}$}

The mass reduction percentage due to the action of $\mathrm{H}_{2} \mathrm{SO}_{4}$ is highest for the normal concrete without PUFS content. Further the mass reduction percentage decreases up to $10-15 \%$ and then it tends to increase for all ages of curing. The mass reduction percentage is reported in Table5.

Table 5. Mass Reduction Percentage for $\mathrm{H}_{2} \mathrm{SO}_{4}$

\begin{tabular}{|l|c|l|c|c|c|c|}
\hline S1. & \multirow{2}{*}{$\begin{array}{l}\text { Mix } \\
\text { No. }\end{array}$} & PUFS & & \multicolumn{4}{|c|}{ Mass Reduction Percentage (\%) } \\
\cline { 4 - 7 } & & 28 Day & 56 Day & 90 Day & 180 Day \\
\hline 1 & 0 & C & 4.07 & 5.63 & 12.03 & 14.96 \\
\hline 2 & 5 & F1 & 3.43 & 3.93 & 11.53 & 14.03 \\
\hline 3 & 10 & F2 & 3.20 & 3.48 & 11.12 & 13.54 \\
\hline 4 & 15 & F3 & 3.70 & 5.30 & 10.86 & 13.03 \\
\hline 5 & 20 & F4 & 4.12 & 6.18 & 11.28 & 13.61 \\
\hline
\end{tabular}

The concrete is found to be fatally deteriorated by the action of $\mathrm{H}_{2} \mathrm{SO}_{4}$ than the action of $\mathrm{HCl}$. The concrete cubes deteriorated with the action of $\mathrm{H}_{2} \mathrm{SO}_{4}$ are shown in Fig. 2.

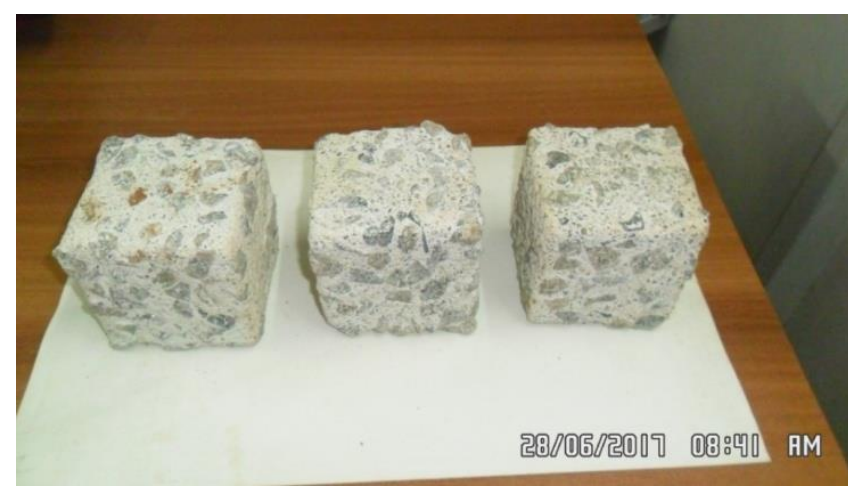

Fig. 2. Concrete cubes deteriorated due to $\mathrm{H}_{2} \mathrm{SO}_{4}$

The compressive strength reduction percentage of concrete without PUFS content exhibits maximum percentage reduction. The reduction percentage for $\mathrm{H}_{2} \mathrm{SO}_{4}$ is decreasing up to $15 \%$ addition of PUFS and then the strength reduction percentage increases. The compressive strength reduction percentage increases with the duration of immersion $\mathrm{H}_{2} \mathrm{SO}_{4}$. However the compressive strength reduction percentage is less than that of the concrete without PUFS content for all curing ages. The compressive strength reduction percentage is reported in Table 6 .

Table 6. Compressive strength reduction $\%$ for $\mathrm{H}_{2} \mathrm{SO}_{4}$

\begin{tabular}{|l|c|c|c|c|c|c|}
\hline S1. & \multirow{2}{*}{$\begin{array}{c}\text { Mix } \\
\text { No. }\end{array}$} & PUFS & & \multicolumn{4}{|c|}{ Compressive Strength Reduction Percentage (\%) } \\
\cline { 4 - 7 } & & 28 Day & 56 Day & 90 Day & 180 Day \\
\hline 1 & 0 & C & 11.11 & 14.29 & 19.78 & 23.91 \\
\hline 2 & 5 & F1 & 10.64 & 13.68 & 18.95 & 22.68 \\
\hline 3 & 10 & F2 & 10.42 & 13.40 & 18.37 & 22.00 \\
\hline 4 & 15 & F3 & 10.00 & 12.87 & 17.65 & 21.36 \\
\hline 5 & 20 & F4 & 10.53 & 13.54 & 18.37 & 22.45 \\
\hline
\end{tabular}

The durability factors for $\mathrm{H}_{2} \mathrm{SO}_{4}$ are reported in Table 7 .

Table 7.Durability factors for $\mathrm{H}_{2} \mathrm{SO}_{4}$

\begin{tabular}{|l|c|l|r|r|r|c|}
\hline Sl. & \multirow{2}{*}{$\begin{array}{c}\text { \% } \\
\text { No. }\end{array}$} & MUFS & & \multicolumn{4}{|c|}{ Durability Factor (\%) } \\
\cline { 4 - 7 } & & 28 Day & 56 Day & 90 Day & 180 Day \\
\hline 2 & 0 & C & 13.83 & 26.67 & 40.11 & 76.09 \\
\hline 3 & 5 & F1 & 13.90 & 26.86 & 40.53 & 77.32 \\
\hline 4 & 10 & F2 & 13.93 & 26.94 & 40.82 & 78.00 \\
\hline 5 & 15 & F3 & 14.00 & 27.11 & 41.18 & 78.64 \\
\hline
\end{tabular}


Graphical representation of durability factors for $\mathrm{H}_{2} \mathrm{SO}_{4}$ is shown in Fig. 3.

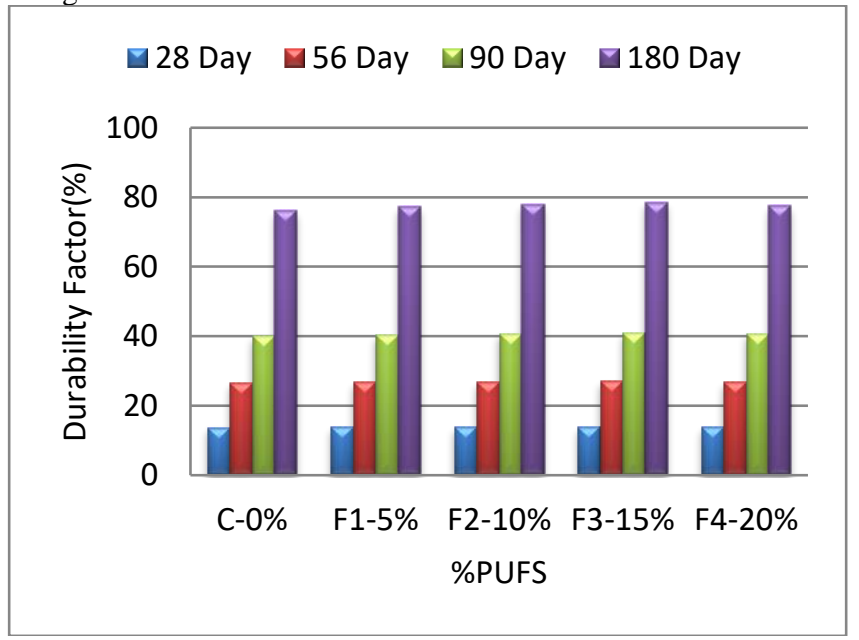

Fig.3.Graph of durability factors for $\mathrm{H}_{2} \mathrm{SO}_{4}$

\section{Sulphate resistance of concrete exposed to $\mathrm{Na}_{2} \mathrm{SO}_{4}$}

No variation is observed with $\mathrm{Na}_{2} \mathrm{SO} 4$ immersed samples for the mass reduction percentage and the compressive strength reduction percentage.

\section{Alkali resistance of concrete exposed to $\mathrm{NaOH}$}

No variation is observed with $\mathrm{NaOH}$ immersed samples for the mass reduction percentage and the compressive strength reduction percentage. The durability factors of $\mathrm{Na}_{2} \mathrm{SO}_{4}$ and $\mathrm{NaOH}$ are reported in Table 8 .

Table 3.Durability factors for $\mathrm{Na}_{2} \mathrm{SO}_{4}$ and $\mathrm{NaOH}$

\begin{tabular}{|l|c|l|r|r|r|r|}
\hline S1. & \multirow{2}{*}{$\begin{array}{c}\text { \% } \\
\text { No. }\end{array}$} & PUFS & & \multicolumn{4}{|c|}{ Durability Factor (\%) } \\
\cline { 4 - 7 } & & 28 Day & 56 Day & 90 Day & 180 Day \\
\hline 1 & 0 & C & 15.56 & 31.11 & 50.00 & 100.00 \\
\hline 2 & 5 & F1 & 15.56 & 31.11 & 50.00 & 100.00 \\
\hline 3 & 10 & F2 & 15.56 & 31.11 & 50.00 & 100.00 \\
\hline 4 & 15 & F3 & 15.56 & 31.11 & 50.00 & 100.00 \\
\hline 5 & 20 & F4 & 15.56 & 31.11 & 50.00 & 100.00 \\
\hline
\end{tabular}

\section{Conclusions}

The concrete containing Pulverized Used Foundry Sand is more resistant to chemical attacks than ordinary concrete without Pulverized Used Foundry Sand. Mass reduction percentage for concrete immersed in $\mathrm{HCl}$ is increasing with the increase in duration of immersion. Compressive strength reduction percentage for concrete immersed in $\mathrm{HCl}$ is increasing with the increase in duration of immersion. Durability factor for concrete immersed in $\mathrm{HCl}$ is increasing with the duration of immersion. Mass reduction percentage for concrete immersed in $\mathrm{H}_{2} \mathrm{SO}_{4}$ is increasing with the increase in duration of immersion. Compressive strength reduction percentage for concrete immersed in $\mathrm{H}_{2} \mathrm{SO}_{4}$ is increasing with the increase in duration of immersion. Durability factor for concrete immersed in $\mathrm{H}_{2} \mathrm{SO}_{4}$ is increasing with the increase in duration of immersion. Mass reduction percentage for concrete immersed in $\mathrm{Na}_{2} \mathrm{SO}_{4}$ and $\mathrm{NaOH}$ is observed to be nil for all durations of immersion. Compressive strength reduction percentage for concrete immersed in $\mathrm{Na}_{2} \mathrm{SO}_{4}$ and $\mathrm{NaOH}$ is observed to be nil for all durations of immersion. Durability factors for concrete immersed in $\mathrm{Na}_{2} \mathrm{SO}_{4}$ and $\mathrm{NaOH}$ is increasing with the increase in duration of immersion. The durability parameters are found to be increasing up to $15 \%$ addition of Pulverized Used Foundry Sand and afterwards it is slightly decreasing. Pulverized Used Foundry
Sand can be effectively added to concrete for attainment of better durable concrete.

\section{Acknowledgement}

The authors would like to express their deep gratitude to Mr.K.N.Madhusoodanan, Managing Director, Mavanal Granites Pvt.Ltd.Kalanjoor, Kerala, India for his constant support on this research. The authors are also thankful to GITAM University and NICMAR for their constant encouragement. The authors also would like to acknowledge Dr.Cini.A, Executive Engineer, National Highway Division, Kollam, Kerala, India for her creative suggestions in this research.

\section{References}

[1] IS 456-2000 Indian Standard-Plain and Reinforced Concrete- Code of Practice, Bureau of Indian Standards, New Delhi, India,2000.

[2] Vagelis G. Papadakis, Costas G. Vayenas, and Michael N. Fardis, "Physical and Chemical Characteristics Affecting the Durability of Concrete," ACI Materials Journal, Vol.88, No.2 (1991), pp 186-196.

[3] N. K. Amudhavalli and Jeena Mathew, "Effect of Silica Fume on the Strength and Durability Parameters of Concrete," International Journal of Engineering Sciences \& Emerging Technologies,Vol.3,No.2(2012),pp 28-35.

[4] S.Sesha Phani, Seshadri Sekhar.T, Srinivasa Rao, P.Sravana and P.Sarika, "Studies on Effect of Mineral Admixtures on Durability Properties of High Strength Self Compacting Concrete," International Journal of Research in Engineering and Technology, Vol.2.No.9 (2013), pp 98-104.

[5] Asma.K.C, Meera.C.M and Preetha Prabhakaran, "Effect of Mineral Admixtures on Durability Properties of High Performance Concrete," International Journal of Engineering Research and Applications, Trends and Recent Advances in Civil Engineering (TRACE- 24th-25th January 2014), pp 33-37.

[6] IS: 12269-1987. Specifications for 53-Grade Ordinary Portland Cement. Bureau of Indian Standards, New Delhi, 1987.

[7] ASTM C33 / C33M-16e1, Standard Specification for Concrete Aggregates, ASTM International, West Conshohocken, PA, 2016.

[8] IS 9103-1999. Concrete Admixture Specification, Bureau of Indian Standards, New Delhi, 1999.

[9] ACI-211.1-1991. American Concrete Institute Guide lines for concrete mix design. American Concrete Institute, 1991.

[10] McGraw-Hill Dictionary of Architecture and Construction. S.v. "durability factor." Retrieved February 102018 from https://encyclopedia2.thefreedictionary.com/durability+factor. 